\title{
Formulation and evaluation of delayed-onset extended-release tablets of metoprolol tartrate using hydrophilic-swellable polymers
}

\author{
SUBHASH CHAND DADARWAL \\ SARIKA MADAN \\ SHYAM SUNDER AGRAWAL* \\ Delhi Institute of Pharmaceutical \\ Sciences and Research (Formerly \\ College of Pharmacy), University \\ of Delhi, Pushp Vihar, Sec-III \\ New Delhi-110017, India
}

Accepted December 28, 2011

\begin{abstract}
In view of the circadian rhythm of cardiovascular diseases, a delayed-onset extended-release (DOER) formulation of metoprolol tartrate (MT) was prepared. This was achieved through dissolution-guided optimization of the proportion of Methocel K4M and Methocel K15M. Core erosion ratio was greater than $50 \%$, thereby showing steady release of the drug after the lag time until complete dissolution. Optimized formulation produced a lag phase of $6 \mathrm{~h}$ followed by complete release of $98.7 \pm 2.1 \%$ in $24 \mathrm{~h}$. Water uptake study revealed that Methocel K15M has lower water uptake $(30 \pm 1 \%)$ than Methocel K4M $(40 \pm 2 \%)$ after $24 \mathrm{~h}$. Axial swelling of polymers was higher than swelling in the radial direction. Drug-polymer interaction study precludes any interaction between drug and polymer. Such a drug delivery system may provide a viable alternative for effective management of hypertension and other related disorders. This work also proposes an approach to attain DOER for a hydrophilic drug by using a hydrophilic swellable polymer in press coat.
\end{abstract}

Keywords: metoprolol tartrate, delayed-onset extended-release (DOER), core erosion ratio

Several studies have demonstrated circadian rhythmicity for all body functions. Incidence of several cardiovascular events, like myocardial infarction, stroke and sudden cardiac death, also exhibit circadian rhythm $(1,2)$. These events are often observed early in the morning as the blood pressure (BP) rises significantly just before waking hours and declines to its lowest value around midnight (3). Lower concentrations of anti-hypertensive drugs during sleep are recommended because excessive reduction in blood pressure during sleep might predispose elderly hypertensive patients to ischaemic cerebrovascular disease (4). Conventional drug delivery systems seem inappropriate to address such medical needs by way of administering drugs, since there is a sharp rise in

*Correspondence; e-mail: agrawal.shyam01@gmail.com 
BP during early hours. However, if these drugs are delivered as sustained release formulations (5), there is a likelihood of excessive reduction in blood pressure during night time. Therefore, there is need to design a delayed-onset extended-release (DOER) system of antihypertensive drugs so that their administration at bedtime would warrant drug release within the therapeutic level in the morning. Chronopharmaceuticals are synonymous with time-delayed-release dosage forms with the onset of release after a pre-programmed time interval (6).

Since $\beta$-blockers such as metoprolol (MT) and carvedilol specifically block the sympathetic drive, they may be particularly effective for suppressing the morning blood pressure surge (7); therefore, MT, which is therapeutically indicated in conditions such as hypertension or angina, was chosen as the model drug in the present study. It belongs to BCS class1 having a half-life of 3-7 $\mathrm{h}$ and plasma protein binding of $12 \%$.

The purpose of this study was to prepare a DOER system of MT by preparing compression-coated core tablets for once a day administration that would provide the desired lag time of about $6 \mathrm{~h}$ followed by sustained release over a period of $24 \mathrm{~h}$. Apart from the in vitro dissolution test, the in vitro core erosion test, effect of rotation speed, effect of $\mathrm{pH}$ and water uptake test were also carried out to understand the behaviour of DOER system in different environments.

\section{EXPERIMENTAL}

\section{Materials}

Metoprolol tartrate was obtained as a gift sample from Astra Zeneca, India. Hydroxypropyl methylcelluloses HPMC (50 mPa s) and Methocel (K4M, E4M, and K15M with viscosity of the order of 4 and $15 \mathrm{~Pa} \mathrm{~s}$ ) were obtained as gift samples from Colorcon Asia Pvt. Limited, India. Commercial tablets of metoprolol (sustained release, $50 \mathrm{mg}$, Astra Zeneca, India) were procured from a local retail pharmacy. All the excipients were of pharmacopoeial grade and other chemicals used were of analytical grade.

\section{Preparation of the core part of press coated tablets}

Press coated tablet formulations (TM1-TM9) were designed as per the composition given in Table I. Core was first prepared by dry mixing of weighed amounts of MT, lactose, and HPMC via screening through a 2-mm pore size sieve. The powder mixture obtained was then subjected to wet granulation using isopropyl alcohol with Methocel E4M as binder. The granules obtained by passing the wet mass through a sieve of pore size 2.38-mm were compressed after air drying at room temperature and addition of suitable amounts of talc and magnesium stearate as glidant and lubricant, respectively. The blend was compressed into tablets using a single punch tablet machine (Jyoti Scientific Industries, India) with 8-mm round and flat faced punches.

\section{Preparation of press coated core tablets}

Coat granulations were prepared prior to preparing complete press coated tablets, using isopropyl alcohol as granulating vehicle. The granules obtained by passing the 
S. C. Dadarwal et al.: Formulation and evaluation of delayed-onset extended-release tablets of metoprolol tartrate using hydrophilic-swellable polymers, Acta Pharm. 62 (2012) 105-114.

Table I. Composition of compression-coated core tablets

\begin{tabular}{|c|c|c|c|c|c|c|c|c|c|}
\hline \multirow{2}{*}{ Ingredient } & \multicolumn{9}{|c|}{ Formulation } \\
\hline & TM1 & TM2 & TM3 & TM4 & TM5 & TM6 & TM7 & TM8 & TM9 \\
\hline \multicolumn{10}{|c|}{ Core part (mg) } \\
\hline $\mathrm{MT}^{\mathrm{a}}$ & 50 & 50 & 50 & 50 & 50 & 50 & 50 & 50 & 50 \\
\hline HPMC (50 mPa s) & 40 & 40 & 40 & 40 & 40 & 40 & 40 & 40 & 40 \\
\hline Lactose & 96 & 96 & 96 & 96 & 96 & 96 & 96 & 96 & 96 \\
\hline Magnesium stearate & 2 & 2 & 2 & 2 & 2 & 2 & 2 & 2 & 2 \\
\hline Talc & 8 & 8 & 8 & 8 & 8 & 8 & 8 & 8 & 8 \\
\hline Methocel E4M & 4 & 4 & 4 & 4 & 4 & 4 & 4 & 4 & 4 \\
\hline Diameter (mm) & 8 & 8 & 8 & 8 & 8 & 8 & 8 & 8 & 8 \\
\hline \multicolumn{10}{|c|}{ Outer layer $(\%, m / m)^{b}$} \\
\hline Methocel K4M & 60 & 42.8 & 33.3 & 0 & 0 & 0 & 28.5 & 33.3 & 24.2 \\
\hline Methocel K15M & 0 & 0 & 0 & 50 & 42.8 & 33.3 & 14.2 & 11.1 & 15.1 \\
\hline Diameter (mm) & 11 & 11 & 11 & 11 & 11 & 11 & 11 & 11 & 11 \\
\hline \multicolumn{10}{|c|}{ Whole tablet $(\%, m / m)^{\mathrm{b}}$} \\
\hline MT & 10 & 14.2 & 16.6 & 12.5 & 14.2 & 16.6 & 14.2 & 13.8 & 15.1 \\
\hline
\end{tabular}

a Drug concentration in the core is $24 \%$.

b Concentration in whole tablet.

wet mass through a sieve of pore size 2.38 - $\mathrm{mm}$ and air drying at room temperature were used to prepare press coated tablets by placing the core tablet in the centre of the die cavity with coat granulations carefully placed in equal proportions both above and below the core tablet. The contents were then compressed using 11-mm round, flat faced punches using a single punch tablet machine.

\section{Drug-excipient interaction study}

Infrared spectroscopy (FTIR). - Infrared spectra of pure MT, physical mixture of the drug and polymers, Methocel K4M, Methocel K15M and the tablet were recorded (Jasco FTIR-410, Japan). All the discs were prepared in a KBr press.

Differential scanning calorimetry (DSC). - Thermograms for five samples, i.e., pure MT, physical mixture of the drug and polymers, Methocel K4M, Methocel K15M and the tablet were recorded using Shimadzu DSC-60 (Japan). The samples were hermetically sealed in aluminium pans and heated at a constant rate of $10{ }^{\circ} \mathrm{C} \mathrm{min}-1$ over the temperature range of $40-200{ }^{\circ} \mathrm{C}$. 
S. C. Dadarwal et al.: Formulation and evaluation of delayed-onset extended-release tablets of metoprolol tartrate using hydrophilic-swellable polymers, Acta Pharm. 62 (2012) 105-114.

\section{Characterization of coated core tablets}

Drug content uniformity. - All the coated tablets were subjected to the test for drug content uniformity as mentioned in Indian Pharmacopoeia (8).

Compressibility test. - To evaluate the compressibility and compactibility, a blend of coat polymer granules (Methocel K4M and Methocel K15M) were compressed as per earlier mentioned conditions and the tensile strength of the six tablets was calculated (9).

Water uptake. - Water uptake of the compression coated tablets comprising of different grades of HPMC was determined in triplicates.

Swelling. - Swelling behaviour of tablets was determined in $0.1 \mathrm{~mol} \mathrm{~L}-1$ hydrochloric acid ( $\mathrm{pH}$ 1.2) and phosphate buffer ( $\mathrm{pH}$ 6.8) as dissolution media. Tablets were immersed in the dissolution medium and the swollen part of each tablet was measured. Percent swelling was then calculated (10).

In vitro core erosion. - In vitro core erosion test was performed on six coated tablets to find the extent of water penetration into the core part of the tablet (11).

In vitro drug dissolution. - The USP type 2 (paddle type) apparatus (12) (Labindia DS 8000 , India) was used to determine the amount of MT released from compression coated core tablets. The paddle rotation speed and temperature were $50 \mathrm{rpm}$ and $37 \pm 0.5^{\circ} \mathrm{C}$, respectively. The dissolution medium was $750 \mathrm{~mL}$ of $0.1 \mathrm{~mol} \mathrm{~L}^{-1} \mathrm{HCl}(\mathrm{pH} 1.2)$ for initial $2 \mathrm{~h}$, subsequent to which $250 \mathrm{~mL}$ of $0.2 \mathrm{~mol} \mathrm{~L}^{-1}$ trisodium phosphate dodecahydrate was added to make the phosphate buffer $\mathrm{pH} 6.8$ up to $24 \mathrm{~h}$. Samples were withdrawn at specific time intervals and analyzed at $272 \mathrm{~nm}$ using a UV spectrophotometer (Shimadzu UV-1601, Japan).

Effect of $\mathrm{pH}$ and rotation speed on the release profile. - Dissolution test was carried out for TM7 in three different dissolution media, $0.1 \mathrm{~mol} \mathrm{~L}^{-1} \mathrm{HCl}(\mathrm{pH} 1.2)$ and phosphate buffers, $\mathrm{pH} 6.8$ and $\mathrm{pH} 7.4$, for $0-2,2-8$ and 8-24 h, respectively. Dissolution tests were also performed at varying rotation speeds of 50,75 and $100 \mathrm{rpm}$ to evaluate effects of the rotation speed on the lag period as well as the drug release behavior.

Effect of different viscosity grades of HPMC. - Two grades of HPMC, Methocel K4M and Methocel K15M, were selected and tablets were prepared by varying the amount of polymer in the press coat while keeping the inner core part the same with respect both to mass and composition. The effect of different viscosity grades of HPMC was recorded with respect to changes in the dissolution profile.

Kinetic assessment of drug dissolution. - The fitness of zero-order, first-order and Higuchi (13) kinetic models was assessed by the coefficient of determination of the curve between the time and amount of drug released. The Korsmeyer-Peppas model was also applied to find out the mechanism of drug release (14). Drug release, from simple swellable systems may be described by the well known Korsmeyer-Peppas kinetic equation:

$$
\frac{M_{t}}{M_{\infty}}=k t^{n}
$$


S. C. Dadarwal et al.: Formulation and evaluation of delayed-onset extended-release tablets of metoprolol tartrate using hydrophilic-swellable polymers, Acta Pharm. 62 (2012) 105-114.

where $M_{t}$ and $M_{\infty}$ are the amounts of drug released at time $t$ and the overall amount released, respectively, whereas $k$ is the release rate constant and $n$ is the release exponent indicative of the release mechanism. When $n$ is 0.45 , the diffusion phenomenon dominates and when $n$ value reaches 0.89 and above, it may be characterized by the case II relaxation release transport and super case II transport. Values of $n$ between 0.45 and 0.89 can be regarded as indicators of anomalous transport.

\section{RESULTS AND DISCUSSION}

\section{Drug-excipient interaction study}

The IR spectra of MT showed the predominant peak $\left(\mathrm{cm}^{-1}\right)$ at 3346.85 for N-H stretching of amino group, 2934.16 for $\mathrm{C}-\mathrm{H}$ stretching of methyl group, 1512.88 for aromatic ring, 1245.79 for $\mathrm{C}-\mathrm{O}$ stretching in aromatic ether, 1111.76 for $\mathrm{C}-\mathrm{O}$ stretching in aliphatic ether, 1298.82 for C-O stretching in secondary alcohol and 821.53 for 1,4-disubstituted benzene. IR spectra of the physical mixture, Methocel K4M, Methocel K15M and the tablet retained all the characteristic peaks of MT and those of Methocel K4M and Methocel K15M with the absence of any additional peaks (Fig. 1). These observations preclude possible interactions between the drug and polymers.

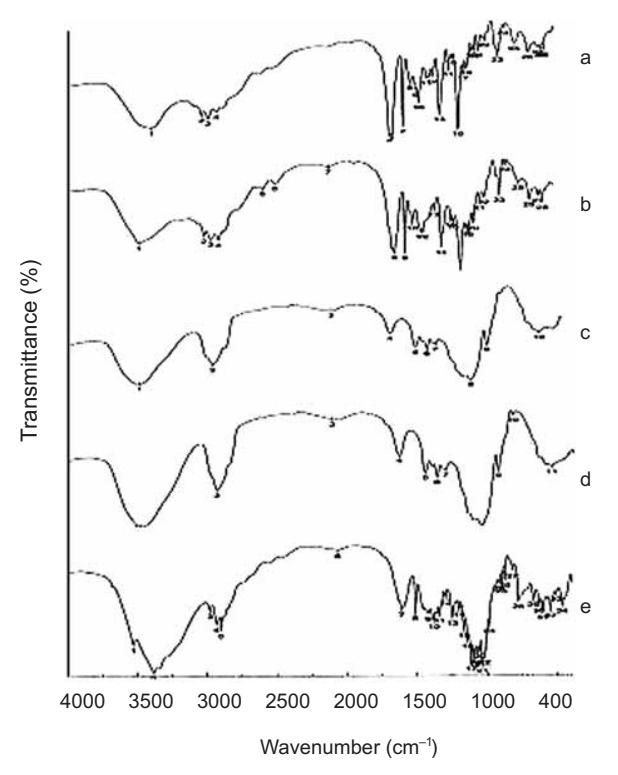

Fig. 1. FTIR spectra of: a) pure MT, b) physical mixture of drug and polymers, c) Methocel K4M, d) Methocel K15M, and e) tablet. 
DSC thermogram of metoprolol tartrate showed a sharp endothermic peak at $123.13^{\circ} \mathrm{C}$ corresponding to its melting point with $567.17 \mathrm{~mJ} \mathrm{~g}^{-1}$ heat of fusion. DSC thermogram of the physical mixture showed MT endotherm at $123.30{ }^{\circ} \mathrm{C}$ with characteristic peaks for the polymers. Tablet formulation showed a shift in peak (123.12 to $\left.116.08^{\circ} \mathrm{C}\right)$. This may be attributed to partial loss of the crystalline character of the drug upon processing (Fig. 2). The absence of any significant change in thermal behavior endorsed the suitability of the drug with selected polymers.

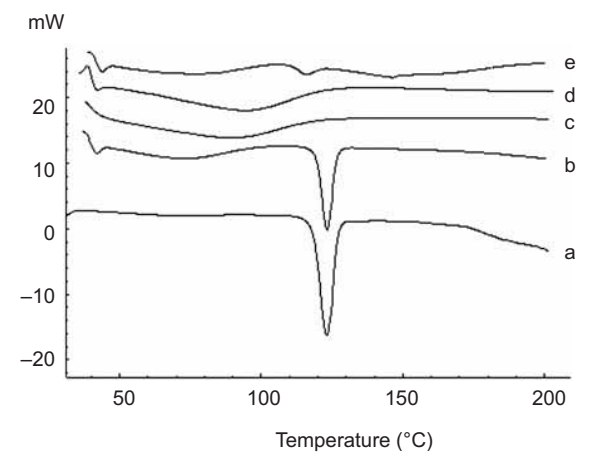

Fig. 2. DSC thermograms of: a) pure MT, b) physical mixture of drug and polymers, c) Methocel K4M, d) Methocel K15M, and e) tablet.

Compressibility and compactibility. - Tensile strength of the coat polymer indicates its compressibility and compactibility for press coat formation. The tensile strength of HPMC was found to be $13.2 \pm 0.8 \mathrm{~kg} \mathrm{~cm}^{-2}$, thereby showing its practical applicability and good compressibility, which is in concordance with previous results (6).

Water uptake and swelling. - Methocel K15M has lower water uptake (30 $\pm 1 \%)$ than Methocel K4M ( $40 \pm 2 \%$ ) after $24 \mathrm{~h}$ though the initial water uptake was the same (about $10 \%$ ) in both cases. These results are in consonance with previous studies (15).

Axial and radial swelling of the polymeric coat on compression coated tablets showed maximum radial swelling of $300 \pm 5$ and $362 \pm 6 \%$ in $0.1 \mathrm{~mol} \mathrm{~L}^{-1} \mathrm{HCl}(\mathrm{pH} 1.2)$ and phosphate buffer ( $\mathrm{pH} 6.8$ ), respectively, while axial swelling was $525 \pm 8$ and $563 \pm 9 \%$ in the same media after $24 \mathrm{~h}$. Axial swelling was found to be higher than swelling in the radial direction, probably due to the release of stress developed during powder compaction along axial direction. These findings were similar to those reported by Dahlberg et al. (16).

In vitro core erosion. - The core erosion ratios of all formulations (TM1 to TM9) were $53,57,51,57,58,60,56,53$ and $52 \%$, respectively, all found to be greater than $50 \%$, thereby showing a steady release of drug after the lag time until complete dissolution. Therefore, tablet probably absorbs water during its transit through the lumen, thereby allowing drug release in the colon in spite of lower amount of water available there for solublizing the drug. These results were found to be in consonance with a previous study by Sawada et al. (11), which also demonstrated that water soluble excipients like lactose monohydrate dissolve to enhance water penetration into the core part. 
In vitro drug dissolution. - The drug content uniformity was found to be in the range of $99-102 \%$ of MT in all formulations. All the formulations (TM1-TM9) subjected to the in vitro dissolution study were swollen. When Methocel $\mathrm{K} 4 \mathrm{M}$ alone was used as a press coat polymer (TM1, TM2 and TM3), it was unable to provide the desirable lag period and sustainability with respect to release (Fig. 3). However, when only Methocel K15M was used in the press coat (TM4, TM5 and TM6), it was unable to release the drug at all, probably because of a thicker gel like network that was formed due to swelling (Fig. 3). However, blending of these two polymers (28.5\% of Methocel K4M and $14.2 \%$ of Methocel $\mathrm{K} 15 \mathrm{M}$ ) in the press coat (TM7) produced a lag phase of $6 \mathrm{~h}$, followed by complete release of $98.7 \pm 2.1 \%$ in $24 \mathrm{~h}$ (Fig. 3). However, tablets prepared with amounts of Methocel K4M lower than $28.5 \%$ in the press coat (TM9) showed a reduction in the lag phase. On the other hand, lowering the amount of Methocel K15M below $14.2 \%$ in the press coat (TM8) compromised the sustainability and lag time for release probably because the lag time got prolonged on increasing the press coat polymer viscosity, which in turn delayed the process of dissolution and/or erosion. However, lowering of the press coat viscosity probably formed a thinner hydrogel layer, thereby facilitating diffusion of the highly soluble drug like MT through the gel layer in a sustained manner for a prolonged period of time. On this basis, tablet formulation TM7 was considered to be optimized, since diffusion of the drug through the formed gel layer and erosion of the gel layer resulted in the drug release process.

The $\mathrm{pH}$ of GIT varies from 1.2 to 8.0 during the tablet transit from the stomach to the colon. Therefore it was imperative to understand the effect of dissolution medium $\mathrm{pH}$ on the release pattern of the drug. In the acidic $\mathrm{pH}$ of the stomach $(\mathrm{pH} 1.2)$, there was a lag in drug release, which continued even when $\mathrm{pH}$ of the medium was raised to $\mathrm{pH} 6.8$ up to $6 \mathrm{~h}(\%$ of drug release $9.3 \pm 1.1)$. About $99.6 \pm 1.7 \%$ of the drug was released after $24 \mathrm{~h}$ upon subsequent change of $\mathrm{pH}$ to 7.4 , which was explicit in a sustained release fashion (Fig. 4).

To further understand how peristaltic motion of GIT may affect the pattern of release from the formulation, an in vitro test was performed at different speeds of the rotating paddle. There was a reduction in the lag period with increasing rotating speed be-

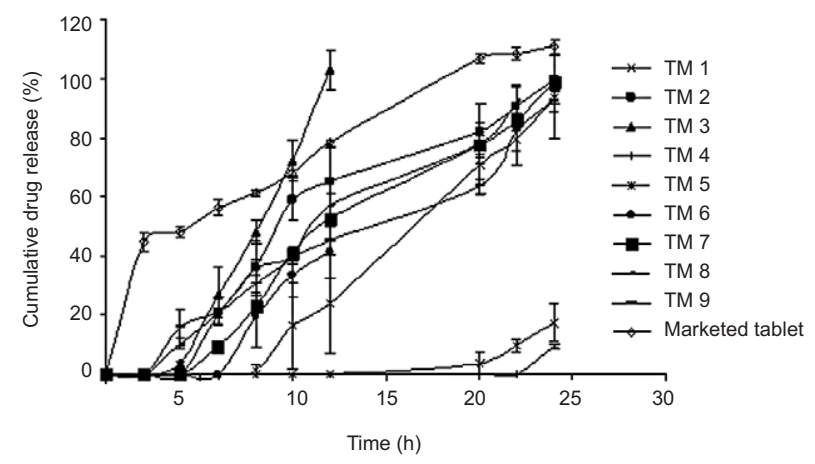

Fig. 3. Dissolution profile of compression-coated core tablets and the commercial tablet. Mean \pm SEM, $n=3$. 


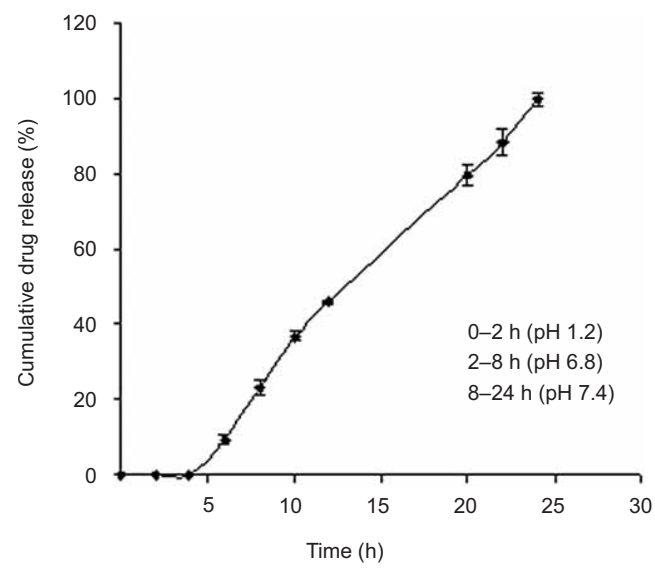

Fig. 4. Effect of $\mathrm{pH}$ on in vitro release of TM7. Mean \pm SEM, $n=3$.

cause of the initial fast diffusion of dissolved drug and easy erosion of the outer layer of the tablet, followed by full gelling of the polymer for complete drug release. However, the overall drug release remained the same with increasing paddle speed.

When a once-a-day tablet formulation of metoprolol available in the market was subjected to in vitro release under the experimental conditions, the drug released in a sustained manner without showing any delayed onset/lag period. In contrast, the administration of MT as a DOER system (TM7) at bedtime can be expected to release the drug after an approximately $6 \mathrm{~h}$ lag period at about $4-5 \mathrm{am}$ in the morning and continue to provide MT in the therapeutic range for the rest of the day.

Kinetic assessment of drug dissolution. - The coefficient of determination for zero-order $\left(R^{2}\right)$ was found to be 0.9786 ; the values were for the first-order, Higuchi and Korsmeyer-Peppas models, $0.7824,0.9674$, and 0.9461 , respectively. They are indicating better correlation with zero-order release, thereby reflecting constant drug release from formulation TM7 up to $24 \mathrm{~h}$. The value of exponent $n$ for Korsmeyer-Peppas model cannot be correlated clearly in this case as $n$ value of 0.1229 fails to interpret the exact mechanism of drug release. These results were found to be in concurrence with literature, which states the absence of any correlation between the $n$ value and diffusion guided release for drug delivery systems based on HPMC (17).

\section{CONCLUSIONS}

Press-coated core tablets of metoprolol tartrate prepared by conventional pharmaceutical processes using different viscosity grades of HPMC showed excellent time-delayed release of the drug. An optimal lag period in both acidic and basic environments, due to the initial swelling of polymers, followed by complete drug release in a controlled manner could be obtained owing mainly to diffusion through the swollen polymer and in part to the slow erosion of the core. Thus, the delayed-onset extended-release system 
S. C. Dadarwal et al.: Formulation and evaluation of delayed-onset extended-release tablets of metoprolol tartrate using hydrophilic-swellable polymers, Acta Pharm. 62 (2012) 105-114.

of metoprolol may be beneficial for alleviating the symptoms of hypertension and related cardiovascular diseases. The results are not only encouraging but they also promise effective management of such diseases through this novel approach after suitable trials in animal models and human beings.

Acknowledgments. - The authors acknowledge the Directorate of Training and Technical Education (DTTE), Government of NCT of Delhi, New Delhi, for providing a senior research fellowship to Mr. SCD. The authors also acknowledge Astra Zeneca Ltd., Bangalore, India, for providing MT as a gift sample.

\section{REFERENCES}

1. B. Lemmer and G. Labrecque, Chronopharmacology and chronotherapeutics: definitions and concepts, Chronobiol. Int. 4 (1987) 319-329; DOI: 10.3109/07420528709083522.

2. S. N. Willich, D. Levy, M. B. Rocco, G. H. Tofler, P. H. Stone and J. E. Muller, Circadian variation in the incidence of sudden cardiac death in the Framingham Heart Study Population, Am. J. Cardiol. 60 (1987) 801-806; DOI: 10.1016/0002-9149(87)91027-7.

3. M. W. Millar-Crag, C. N. Bishop and E. B. Raftery, Circadian variation of blood-pressure, Lancet 311 (1978) 795-797; DOI: 10.1016/S0140-6736(78)92998-7.

4. K. Kario, T. Matsuo, H. Kobayashi, M. Imiya, M. Matsuo and K. Shimada, Nocturnal fall of blood pressure and silent cerebrovascular damage in elderly hypertensive patients, Hypertension 27 (1996) 130-135.

5. S. P. Boldhane and B. S. Kuchekar, Development and optimization of metoprolol succinate gastroretentive drug delivery system, Acta Pharm. 60 (2010) 415-425; DOI: 10.2478/v10007-010-0031-x.

6. H. Zou, X. Jiang, L. Kong and S. Gao, Design and evaluation of a dry coated drug delivery system with floating-pulsatile release, J. Pharm. Sci. 97 (2008) 263-273; DOI: 10.1002/jps.21083.

7. D. S. Hanes and M. R. Weir, The beta blockers: are they as protective in hypertension as in other cardiovascular conditions? J. Clin. Hypertens. 3 (2001) 236-243; DOI: 10.1111/j.1524-6175.2001. 00444.x.

8. Indian Pharmacopoeia, 6 th ed., Government of India, Ministry of Health and Family Welfare, Delhi 2010, pp. 1681-1683.

9. J. T. Fell and J. M. Newton, Determination of tablet strength by the diametral-compression test, J. Pharm. Sci. 59 (1970) 688-691; DOI: 10.1002/jps.2600590523.

10. J. Nunthanid, M. Luangtana-anan, P. Sriamornsak, S. Limmatvapirat, K. Huanbutta and S. Puttipipatkhachorn, Use of spray-dried chitosan acetate and ethylcellulose as compression coats for colonic drug delivery: effect of swelling on triggering in vitro drug release, Eur. J. Pharm. Biopharm. 71 (2009) 356-361; DOI: 10.1016/j.ejpb.2008.08.002.

11. T. Sawada, K. Sako, M. Fukui, S. Yokohama and M. Hayashi, A new index, the core erosion ratio, of compression-coated timed-release tablets predicts the bioavailability of acetaminophen, Int. J. Pharm. 265 (2003) 55-63; DOI: 10.1016/S0378-5173(03)00405-8.

12. United States Pharmacopeia XXXII, National Formulary XXVII, USP Convention, Rockville (MD) 2009, pp. 263-275.

13. T. Higuchi, Mechanism of sustained-action medication: theoretical analysis of rate of release of solid drugs dispersed in solid matrices, J. Pharm. Sci. 52 (1963) 1145-1149; DOI: 10.1002/jps. 2600521210. 
S. C. Dadarwal et al.: Formulation and evaluation of delayed-onset extended-release tablets of metoprolol tartrate using hydrophilic-swellable polymers, Acta Pharm. 62 (2012) 105-114.

14. R. W. Korsmeyer, R. Gurny, E. Doelker, P. Buri and N. A. Peppas, Mechanisms of solute release from porous hydrophilic polymers, Int. J. Pharm. 15 (1983) 25-35; DOI: 10.1016/0378-5173(83) 90064-9.

15. L. W. Cheong, P. W. S. Heng and L. F. Wong, Relationship between polymer viscosity and drug release from a matrix system, Pharm. Res. 9 (1992) 1510-1514; DOI: 10.1023/A:1015883501871.

16. C. Dahlberg, A. Fureby, M. Schuleit, S. V. Dvinskikh and I. Furo, Polymer mobilization and drug release during tablet swelling, A 1H NMR and NMR microimaging study, J. Control. Release 122 (2007) 199-205; DOI: 10.1016/j.jconrel.2007.07.007.

17. J. Siepmann and N. A. Peppas, Modeling of drug release from delivery system based on hydroxypropyl methylcellulose (HPMC), Adv. Drug Deliv. Rev. 48 (2001) 139-157; DOI: 10.1016/ S0169-409X(01)00112-0.

\author{
$S A \check{Z} E T A K$
}

\title{
Priprava i vrednovanje tableta metoprolol tartarata s odgođenim i produljenim oslobađanjem koristeći hidrofilne polimere koji bubre
}

SUBHASH CHAND DADARWAL, SARIKA MADAN I SHYAM SUNDER AGRAWAL

Vodeći računa o cirkadijanom ritmu kardiovaskularnih bolesti, pripravljene su formulacije metoprolol tartarata (MT) s odgođenim i produljenim oslobađanjem (DOER). Optimizacija je provedena praćenjem oslobađanja pri čemu je mijenjan omjer hidroksipropilmetil celuloza Methocela K4M i Methocela K15M. Erozija obložnog sloja bila je veća od $50 \%$, što pokazuje ujednačeno oslobađanje ljekovite tvari nakon početne odgođene faze do potpunog oslobađanja. U optimiziranoj formulaciji oslobađanje je započelo nakon $6 \mathrm{~h}$, nakon čega slijedi potpuno oslobađanje $(98.7 \pm 2.1 \%)$ tijekom 24 h. Nakon 24 h ulazak vode u Methocel K15M bio je manji (30 $\pm 1 \%$ ) nego u Methocel K4M (40 2 \%). Aksijalno bubrenje polimera bilo je značajnije nego radijalno bubrenje. Nije zapažena interakcija lijeka i polimera. Opisani sustav za isporuku lijekova može biti korisna alternativa za učinkovitu terapiju hipertenzije i srodnih poremećaja. DOER s ovojnicom od hidrofilnih polimera koji bubre upotrebljiv je i za druge hidrofilne lijekove.

Ključne riječi: metoprolol tartarat, odgođeno i produljeno oslobađanje (DOER), erozija ovojnice

Delhi Institute of Pharmaceutical Sciences and Research (Formerly College of Pharmacy) University of Delhi Pushp Vihar, Sec-III, New Delhi-110017, India 